\title{
MODEL IMPLEMENTASI BIOENGINEERING SEBAGAI UPAYA MITIGASI LONGSOR
}

(Kajian di Lokasi Rawan Longsor Desa Jatiradio, Kecamatan Cililin, Kabupaten Bandung Barat)

\section{BIOENGINEERING IMPLEMENTATION MODEL AS LANDSLIDE MITIGATION EFFORT}

\author{
(Study in Landslide Hazard Area, Jatiradio Village, Cililin District, West Bandung \\ Regency)
}

\author{
Hasmana Soewandita ${ }^{1}$ \\ ${ }^{1}$ Pusat Teknologi Reduksi Risiko Bencana (PTRRB) - BPPT \\ Gedung 820, PUSPIPTEK, Kota Tangerang Selatan, telepon: (021) 75791378 \\ e-mail: hasmana.soewandita@bppt.go.id
}

\begin{abstract}
Landslide is one of the high frequency disasters that occur in Indonesia. The incident recurs every year with a different location. The fact that landslide hazards are used intensively for agricultural cultivation due to economic considerations. One of the efforts to mitigate this disaster is the Bioengineering implementation approach. Bioenginering activity is the application of landslide hazard area management by managing plants / vegetation. The purpose of this research is to implement a vegetative technology implementation model as an effort to mitigate landslides. Bioenginering implementation is designed with a combination of ecological and socioeconomic approaches. The results of this combination are consulted with the affected community and consider various vegetation alternatives. The selected vegetation not only has an ecological function but also an economic function. With these considerations, a vegetation design is obtained with a combination of upper strata (trees), middle and lower strata. For the upper strata, it is recommended to plant Petai (Parkia speciosa) and Durian (Durio zibenthinus), for the middle strata, namely Coffee (Coffea arabica) and lower strata plants are Pineapple (Ananas commocus). The combination of plants such as the implementation at the field level will be accepted by the farming community, because every certain period of time the farmers will be able to harvest their crops without having to remove the plants or cut down the plants. Maintaining the level of land cover and land use has implications for maintaining the stability of soil moisture conditions which in turn can reduce the threat of landslides in landslide hazard areas.
\end{abstract}

Keyword : implementation, bioengineering, vegetative, mitigation, landslide

\begin{abstract}
ABSTRAK
Longsor merupakan salah satu bencana dengan intensitas tinggi yang terjadi di Indonesia. Kejadiannya berulang tiap tahun dengan lokasi yang berbeda-beda. Kenyataan bahwa lahan rawan longsor dimanfaatkan secara intensif untuk budidaya pertanian karena pertimbangan ekonomi. Salah satu upaya untuk mitigasi bencana ini adalah pendekatan implementasi bioengineering, yaitu penerapan pengelolaan lahan rawan longsor dengan mengelola tanaman/vegetasi. Tujuan dari penelitian ini adalah mengimplementasikan model teknologi vegetatif atau bioengineering sebagai bagian upaya mitigasi bencana longsor. Implementasi bioenginering dirancang dengan perpaduan pendekatan ekologi dan sosial ekonomi. Konsep yang dikonsultasikan dengan masyarakat terdampak serta mempertimbangkan alternatif vegetasi yang mempunyai fungsi ekologi didapat desain rancangan vegetasi dengan perpaduan vegetasi strata atas (pohon), strata menengah, dan strata bawah. Untuk strata atas direkomendasikan tanaman Petai (Parkia speciosa) dan Durian (Durio zibenthinus), untuk strata menengah yaitu Kopi (Coffea arabica) dan tanaman strata bawah adalah Nanas (Ananas commocus). Dengan perpaduan tanaman seperti tersebut di atas, implementasi di tingkat lapangan akan bisa diterima oleh masyarakat petani, karena setiap tempo kurun waktu tertentu petani akan bisa melakukan panen hasil tanamannya tanpa harus mecabut tanaman atau menebang tanaman yang
\end{abstract}


mana selama ini dilakukan. Mempertahankan tingkat tutupan lahan dan penggunaan lahan akan berimplikasi pada terjaminnya kestabilan kondisi kelembaban tanah yang akhirnya dapat mengurangi ancaman bahaya longsor di kawasan rawan longsor.

Kata kunci : implementasi, bioengineering, vegetatif, mitigasi, longsor

\section{PENDAHULUAN}

\section{$1.1 \quad$ Latar Belakang}

Longsor merupakan salah satu bencana hidrometeorologi yang intensitas kejadiannya tiap tahun selalu tinggi. Berdasarkan Data dan Informasi Bencana Indonesia Badan Nasional Penanggulangan Bencana (BNPB) yang dirilis tahun 2020, jumlah kejadian longsor yang terjadi pada tahun 2019 adalah 1.481 kali. Kejadian longsor sering terjadi pada awal musim penghujan saat intensitas hujan sudah mulai tinggi. Didahului oleh kondisi musim kemarau yang panjang dan ekstrim, menyebabkan tanah yang berada pada lahan miring dengan keterbukaan lahan relatif besar tidak mampu menyerap air secara seimbang, sehingga terjadi unsteady state yang akhirnya terjadi longsor.

Berbagai aspek yang menjadi penyebab kejadian longsor adalah sangat kompleks, dari mulai sifat kondisi permukaan tanah hingga karakateristik bawah permukaan tanah. Kondisi permukaan tanah seperti kelerengan tanah, keterbukaan tanah oleh tutupan lahan, pola pengelolaan lahan, sifat fisik tanah bahkan juga kondisi kesuburan tanah. Pemicu longsor dipengaruhi oleh dinamika intensitas curah hujan. Kejadian longsor yang selama ini terjadi umumnya dipicu oleh intensitas hujan tinggi. Fakta menunjukkan kejadian longsor terjadi setelah beberapa hari terjadi hujan. Peningkatan resapan air ke dalam tanah, pada suatu kondisi tertentu meningkatkan kapasitas tanah menyimpan air hingga menjenuhkan lapisan tanah dengan tekstur pasiran. Tingkat penjenuhan air yang berada pada lapisan bidang gelincir (bisa berupa lapisan liat) akan memicu terjadinya longsor. Dampak kerusakannya antara lain berupa berubahnya permukaan tanah serta hilangnya lapisan tanah atas dan vegetasi (Kurnia dkk., 2005). Vegetasi merupakan faktor penting dalam menjaga kemantapan lereng, karena ketiadaan tumbuhan atau pepohonan di daerah pegunungan akan sangat mempengaruhi proses longsor. Menurut Asdak (2003), pengaruh vegetasi penutup tanah adalah untuk melindungi permukaan tanah dari tumbukan air hujan, menurunkan kecepatan dan volume air larian, menahan partikel-pertikel tanah pada tempatnya melalui sistem perakaran dan serasah yang dihasilkan dan mempertahankan kemantapan kapasitas tanah dalam menyerap air. Adanya vegetasi penutup tanaman yang baik seperti rumput yang tebal atau hutan yang lebat dapat menghilangkan pengaruh topografi terhadap erosi yang akan berakibat pada terjadinya longsor. Hal yang tidak disadari bahwa kondisi kesuburan tanah pada suatu daerah lereng, karena kondisi sosial ekonomi di kawasan tersebut akan menggiring pola pengelolaan lahan yang seharusnya untuk kawasan konservasi menjadi kawasan budidaya. Beberapa kejadian longsor seperti di Karangkobar, Kabupaten Banjarnegara tahun 2014 dan di Desa Banaran, Kabupaten Ponorogo tahun 2017, kejadian tanah longsor terjadi pada kawasan budidaya. Hal ini karena kawasan berlereng tersebut merupakan kawasan lahan yang mempunyai solum tanah tebal, gembur dan secara kimiawi tanah tersebut tergolong subur. Pemanfaatan lahan rawan longsor terkadang memang tidak disadari, mengingat kebutuhan ekonomi lebih dipertimbangkan daripada bahayanya. Sehingga kawasan lahan berlereng dirambah untuk aktivitas budidaya karena juga didukung oleh kondisi kesuburan lahannya. Pemanfaatan budidaya yang terkadang tidak disadari adalah untuk budidaya tanaman semusim, sehingga lahan dilakukan pengolahan secara intensif, serta keterbukaan lahannya lebih terbuka dibandingkan dengan tanaman konservasi yang seharusnya dilakukan.

\subsection{Tujuan}

Tujuan dari kajian ini adalah mengimplementasikan model teknologi vegetatif atau bioengineering sebagai bagian upaya mitigasi bencana longsor. Memberikan alternatif formulasi pola penanaman sesuai kaidah sosial ekonomi dan ekologi dalam implementasi mitigasi bencana longsor. 


\section{METODOLOGI}

\subsection{Lokasi}

Lokasi kajian berada di wilayah Desa Jatiradio, Kecamatan Cililin, Kabupaten Bandung Barat. Lokasi ini merupakan wilayah rawan longsor.

\subsection{Metode}

Metode yang dilakukan pada kegiatan penelitian ini lebih bersifat melakukan pentahapan kegiatan untuk tercapainya implementasi. Adapun metode dan tahapan yang dilakukan adalah sebagai berikut:

- Memetakan lokasi rawan longsor berdasarkan karakteristik biofisik. Metode yang dilakukan dengan analisis spasial kondisi rawan longsor berdasarkan parameter-parameter yang berpengaruh seperti kondisi kelerengan, jenis dan ketebalan tanah, tutupan lahan, dan kondisi geologi.

- Melakukan analisis vegetasi berdasarkan tipologi fisiologi tanaman. Metode yang digunakan adalah analisis fisiologi tanaman (fisik) berdasarkan strata tinggi dan besar tanaman. Seperti tanaman pohon (berbatang besar), tanaman tengah (perdu), dan tanaman bawah.

- Melakukan analisis sosial ekonomi vegetasi. Metode yang digunakan adalah menjaring partisipasi masyarakat dalam penentuan komoditas tanaman yang diusulkan berdasarkan pendekatan nilai ekonomi dan ekologi. Metode ini digunakan untuk mensinergikan aspek ekologi dan ekonomi. Sehingga kepentingan ekologi bisa mendukung ketahanan nilai ekonomi dan sosial masyarakat di lokasi rawan longsor.

- Melakukan rekomendasi model implementasi bioengineering. Metode yang digunakan adalah memilih kombinasi jenis tanaman berdasarkan strata ketinggian tajuk (atas, tengah, dan bawah) sehingga dengan perpaduan kombinasi tutupan tajuk tersebut, persentase tutupan lahan akan lebih baik dan efek energi percikan hujan akan berkurang, sehingga degradasi terhadap permukaan tanah dapat direduksi.

- Melakukan pengujian dan implementasi bioengineering. Metode yang dilakukan adalah melakukan pelaksanaan penanaman vegetasi sesuai dengan rekomendasi terpilih.

\section{MEKANISME LONGSOR}

\subsection{Faktor Statis}

\section{a. Kelerengan}

Kelerengan merupakan salah satu faktor yang menyebabkan pemicu terjadinya longsor. Makin besar sudut kelerengan potensi ancaman longsor makin tinggi meskipun faktor-faktor lain juga turut menentukan. Faktor kelerengan juga bisa merepresentasikan tingkat kestabilan lereng.

\section{b. Karakteristik Tanah (Tesktur, Struktur, dan Kesuburan)}

Karakteristik tanah merupakan salah satu faktor yang menentukan tanah mudah terganggu atau tidak. Tekstur tanah yang dominan pasiran tentunya akan mudah rentan terhadap longsoran, hal ini dikarenakan tingkat kohesifitas partikel tanah rendah. Sementara tanah dengan tingkat liat tinggi akan mempunyai daya ikat antar partikel yang lebih tinggi. Struktur tanah berkaitan dengan tingkat kegemburan tanah. Tanah yang gembur dan solumnya tebal biasanya subur. Karena kondisi demikian sering sekali dimanfaatkan untuk lahan budidaya pertanian. Pada kondisi tanah miring, hal ini akan mempunyai tingkat kerentanan yang tinggi.

Infiltrasi juga bagian karakteristik tanah dimana tekstur yang akan mempengaruhi tingkat peresapan air permukaan/air hujan masuk ke dalam tanah. Berkaitan dengan tekstur, tentunya juga ada hubungannya dengan porositas. Laju infiltrasi pada tanah yang porous lebih tinggi dibandingkan dengan laju infiltrasi pada lapisan tanah yang tidak porous.

Terlihat seperti grafik pada Gambar 1, tanah dengan tekstur pasiran, laju infiltrasinya lebih tinggi dan tercapai tingkat laju yang stabil lebih cepat dibandingkan dengan tanah dengan tekstur debu maupun tekstur liat. Artinya, tanah dengan tekstur dominan pasiran akan mudah menyerap air (hujan). Kondisi keterbukaan tanah yang minim tutupan lahan/vegetasi juga akan mempercepat terjadinya penyerapan air ke dalam tanah. 


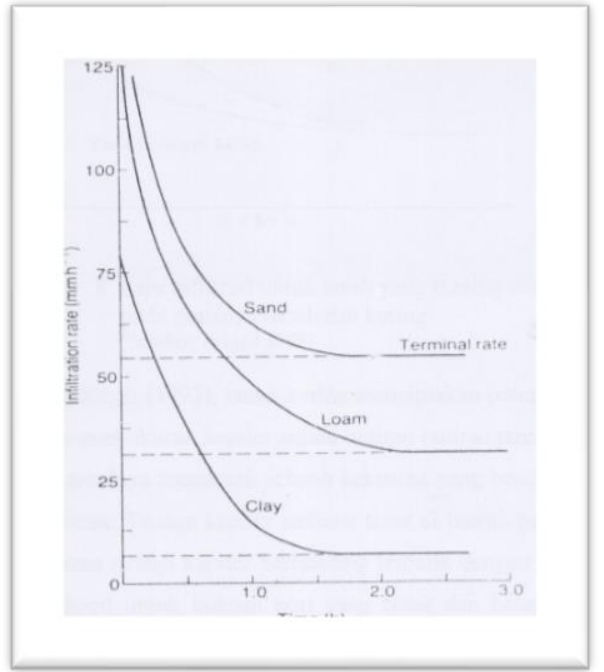

Gambar 1. Laju Infiltrasi pada Beragam Tipe Tanah (Sumber: Morgan, 1986)

\section{c. Geologi (Litologi)}

Faktor geologi sering menjadi faktor penentu, apakah lokasi itu stabil atau rentan. Adanya lapisan kedap atau impermeable pada suatu lereng, maka lokasi itu menjadi lebih rentan terhadap longsor karena lapisan tersebut akan menjadi bidang gelincir dari suatu massa tanah yang berada diatasnya seiring dengan faktor-faktor lain yang berpengaruh terpenuhi. Kondisi geologi berupa kontak antara zona lapukan dengaan batuan dasar sering menjadi penyebab terjadinya longsor (Hidayat dkk., 2016).

\subsection{Faktor Dinamis}

\section{a. Curah Hujan}

Kejadian longsor setelah faktor-faktor yang berpengaruh terpenuhi, salah satu faktor dinamis yang mempengaruhi dan sering menjadi pemicu adalah faktor hujan. Sering kejadian longsor diawali dengan kejadian curah hujan dengan durasi yang lama. Kejadian hujan yang lama menimpa permukaan tanah, akan mengakibatkan penjenuhan air pada suatu massa tanah. Penjenuhan dan atau pengisian air pada lapisan tanah, terkadang akan mengakibatkan ketidakstabilan lereng di atas massa tanah tersebut. Sehingga hal ini akan memicu terjadinya longsor. Curah hujan merupakan salah satu faktor pemicu terjadinya tanah longsor (Kawamoto dkk., 2000). Tingginya intensitas curah hujan dapat menambah beban pada lereng sebagai akibat peningkatan kandungan air dalam tanah, yang pada akhirnya memicu terjadinya longsoran (Huang dan Lin, 2002).

\section{b. Vegetasi}

Peran vegetasi asli cukup signifikan dalam pencegahan tanah longsor dan juga untuk menstabilkan tanah longsor. Tutupan tanaman tidak hanya melindungi permukaan dari pelapukan karena untuk mengarahkan dampak hujan dan angin tetapi sistem akarnya yang rumit bekerja sebagai suatu kesatuan mengikat tanah yang longgar dan mencegahnya dari erosi. Ketika ditanam dan dipelihara dengan baik, vegetasi dapat melindungi lereng dengan mengurangi erosi, memperkuat tanah, dan menghambat tanah longsor yang meningkatkan stabilitas lereng umum. Vegetasi tanaman mempunyai kaitan dengan tingkat pembasahan pada suatu lahan dan hal ini mempengaruhi stabilitas lereng. Pada bagian atas (canopy), tanaman bisa mengintersepsi hingga $26,73 \%$ dari curah hujan. Sedangkan $10,78 \%$ curah hujan bisa dipusatkan pada sekitar batang pohon tersebut. Hasil penelitian terhadap vegetasi, berhasil memprediksi hisapan matriks yang berasal dari tanaman untuk mengevaluasi efek hidrologi pada kejadian longsor (Gonzalez dan Mickovski , 2017).

Penggunaan vegetasi untuk mengelola erosi dan melindungi lereng relatif tidak mahal, dapat berfungsi membangun habitat satwa liar, dan dapat meningkatkan kualitas estetika lahan. Gray dan Leiser (1982) meneliti bahwa efek utama dari tanaman/vegetasi pada tingkat lebih rendah, dan vegetasi kayu atau pohon dalam mengendalikan tanah longsor dan gerakan massa termasuk diantaranya:

- Intersepsi: Dedaunan dan residu tanaman menyerap energi hujan dan mencegah pemadatan tanah dari tetesan hujan.

- Pengekangan: Sistem akar secara fisik mengikat atau menahan partikel tanah ketika berada di atas tanah residu menyaring sedimen keluar dari limpasan.

- Retardasi: Residu di atas tanah meningkatkan kekasaran permukaan dan kecepatan limpasan yang lambat.

- Infiltrasi: Akar dan residu tanaman membantu menjaga porositas dan permeabilitas tanah.

- Transpirasi: Menipisnya kelembaban tanah oleh tanaman menunda timbulnya saturasi dan limpasan.

Vegetasi, terutama tanaman kayu, juga membantu mencegah gerakan massa, khususnya 
tegangan geser dangkal di lereng. Faktor-faktor yang mempengaruhi stabilitas lereng dikelompokkan oleh Varnes (1958) menjadi yang cenderung meningkatkan tegangan geser dan yang cenderung mengurangi resistensi geser. Ini memberikan dasar untuk memberikan kemungkinan pengaruh vegetasi dalam mengatur stabilitas tanah longsor. Kemungkinan cara vegetasi dapat mempengaruhi keseimbangan gaya geser di lereng termasuk:

- Penguatan akar: Akar secara mekanis memperkuat tanah dengan mentransfer tegangan geser tanah untuk ketahanan tarik di akar.

- Modifikasi kelembaban tanah: Evapotranspirasi dan intersepsi dalam batas dedaunan membangun stres kelembaban tanah. Vegetasi juga mempengaruhi laju pencairan salju, yang pada gilirannya mempengaruhi rezim kelembaban tanah.

- Buttressing dan arching: Batang berlabuh dan tertanam dapat bertindak sebagai buttress heap atau abutment lengkung di lereng, menangkal tegangan geser.

- Biaya tambahan: Berat vegetasi pada lereng memberikan kemiringan (destabilisasi) tegangan dan komponen tegangan tegak lurus dengan kemiringan yang cenderung meningkat resistensi terhadap tegangan geser.

- Root Wedging: Dugaan kecenderungan akar untuk menimbulkan retakan, celah, dan saluran dalam massa tanah atau batu dan dengan demikian menyebabkan ketidakstabilan lokal.

Bradshaw (1987) memproyeksikan pentingnya tutupan vegetatif untuk mencapai kondisi yang stabil dan mandiri. Vegetasi merupakan faktor pengaturan terhadap rekonstruksi suatu ekosistem dari tanah longsor, karena meningkatkan keanekaragaman fisik dan biologis situs yang terganggu. Revegetasi seharusnya menjadi alat terbaik untuk stabilisasi degradasi habitat (Singh et al., 2002) karena vegetasi tidak hanya menyediakan stabilisasi ekosistem jangka panjang dan memberikan efek perbaikan potensial pada kualitas tanah, tetapi juga memiliki nilai potensial (Torbert et al., 1993).

\section{c. Penggunaan Lahan}

Hasil penelitian ini sesuai dengan pendapat Rupaka (2015) bahwa sebaran longsor lahan tergantung karakteristik wilayah setempat yang juga di pengaruhi curah hujan, vegetasi, dan peningkatan beban massa tanah. Beban massa tanah yang bertambah biasanya diakibatkan adanya pengalih fungsi lahan seperti pertanian ke permukiman. Penggunaan lahan dengan vegetasi yang tidak sesuai dengan kondisi fisik daerah juga menyebabkan masalah lingkungan terutama kejadian longsor lahan. Vegetasi mempunyai pengaruh yang bersifat melawan terhadap pengaruh faktor-faktor lain yang erosif seperti hujan, topografi, dan karakteristik tanah (Indracahya dkk., 2015). Vegetasi yang terdapat pada perkebunan/kebun harus sesuai dengan kondisi fisik daerahnya, misalnya pada bagian lereng, tanaman yang ditanam sebaiknya ditanami tanaman tahunan yang memiliki sistem perakaran yang dalam seperti pinus, sengon, jati, mahoni, cengkeh dan lain sebagainya. Pada wilayah tersebut sebaiknya bukan ditanami tanaman yang membutuhkan tanah gembur, karena tanah gembur akan mempercepat terjadinya longsor lahan. Tipe penggunaan lahan juga akan berpengaruh terhadap penyerapan air ke dalam tanah/infiltrasi. Berkaitan dengan infiltrasi, penggunaan lahan dengan tutupan vegetatif akan menyediakan perlindungan dari pemadatan oleh energi air hujan. Namun, besarnya infiltrasi tergantung pada fase pertumbuhan. Tanah dengan tanaman jagung dewasa memiliki infiltrasi yang lebih besar dibandingkan dengan jagung yang baru ditanam. Menurut Rawls et al. (1998), peningkatan infiltrasi ini disebabkan oleh peningkatan bukaan akar dan perlindungan daundaunan dewasa yang melindungi tanah dari pemadatan oleh air hujan.

\section{DESAIN IMPLEMENTASI}

\subsection{Pertimbangan Implementasi}

\section{a. Kelerengan Terjal}

Dalam survei pemilihan lokasi telah dilakukan ground check lokasi sekitar lokasi rawan longsor yang dicurigai mempunyai potensi indikasi untuk implementasi teknologi bioengineering. Lokasilokasi yang dipilih mempunyai beberapa pertimbangan seperti:

- Lereng curam

- Keterbukaan terhadap tutupan lahan tinggi atau Indek intensitas vegetasi rendah

- Kawasan budidaya yang diolah baik secara intensif atau temporer

- Pola budidaya kurang mengikuti kaidah konservasi tanah maupun mitigasi bencana longsor

- Solum tanah tebal

- Struktur tanah gembur 


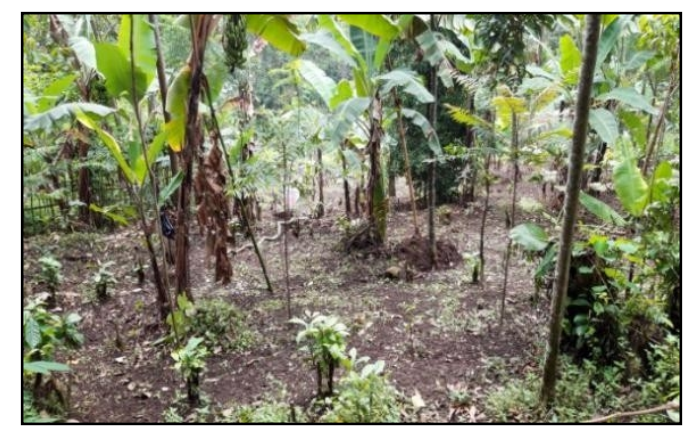

Gambar 2. Lahan yang Berpotensi untuk

Dilakukan Implementasi Bioengineering karena

Keterbukaan Lahan yang Masih Rendah

Sebagaimana terlihat pada Gambar 2, lahan telah dilakukan pengelolaan budidaya secara intensif dengan mulitiple cropping, akan tetapi tidak terpola secara baik, seperti rendahnya intensitas tanaman. Sehingga energi pukulan air hujan akan lebih intensif mengenai permukaan tanah dan secara langsung ataupun tidak langsung memberi pengaruh terhadap keseimbangan neraca air tanah pada sebidang tanah tersebut. Implikasinya berpengaruh terhadap potensi peluang terjadinya ketidakseimbangan massa air dan tanah dalam bahaya longsor.

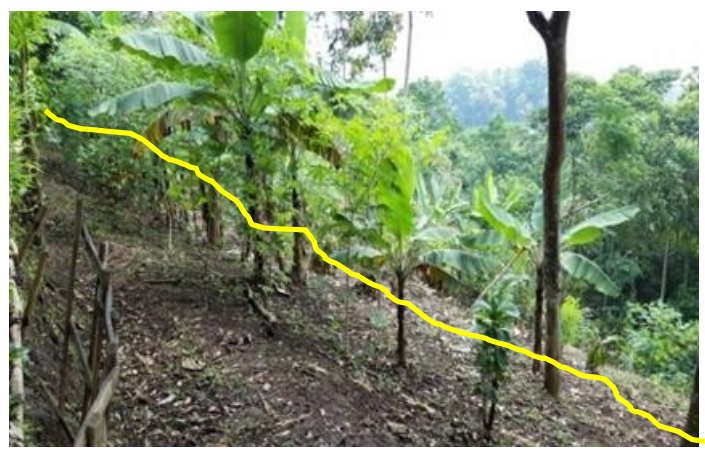

Gambar 3. Lahan Berlereng, Keterbukaan Lahannya Tinggi, Gembur, dan Telah Dilakukan Pola Budidaya Intensif

Begitu juga seperti pada Gambar 3 dan Gambar 4, lokasi berlereng dengan intensitas tanaman rendah, solum tanah dalam, sudah dilakukan pola budidaya secara intensif akan tidak terpola secara baik. Kondisi lokasi yang demikian ini direkomendasikan untuk dilakukan implementasi teknologi bioengineering.

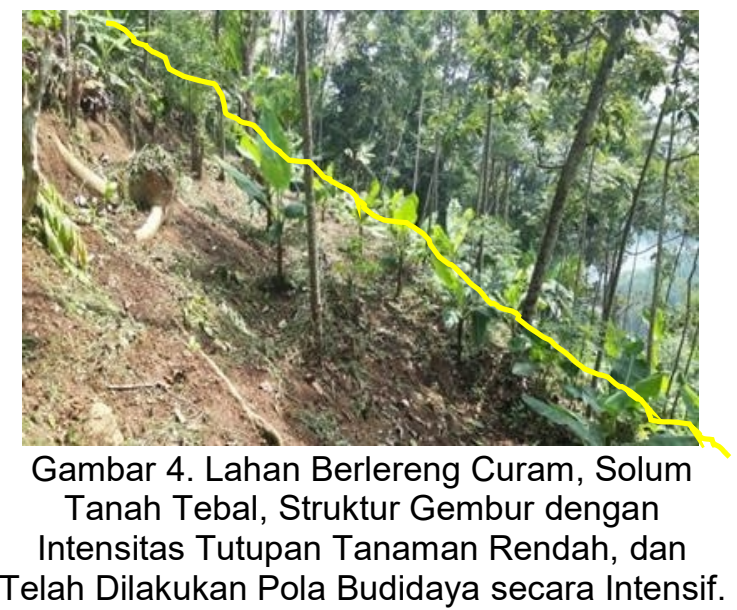

b. Pertimbangan Sosial Ekonomi Masyarakat

Dalam implementasi vegetasi sebagai teknologi Bioengineering untuk mitigasi bencana longsor, permasalahan mendasar yang perlu dipertimbangkan adalah pemilihan vegetasi yang secara sosial ekonomi bisa diterapkan di tingkat lapangan. Secara faktual di lapangan, permasalahan vegetasi yang telah tumbuh dan dikelola masyarakat semata hanya untuk mengejar kepentingan pragmatis asal-asalan dan kurang memberi pertimbangan nilai ekonomi sekaligus ekologis dan kebencanaan. Artinya tanaman yang dipilih terkesan apa adanya tumbuh secara liar. Meskipun demikian, kenyataan di lapangan sekitar Jatiradio, Cililin, beberapa petani telah menerapkan pola budidaya yang sangat baik dengan mempertimbangkan nilai ekonomi dan ekologi, namun belum sepenuhnya terkelola secara optimal.

Dalam pemilihan vegetasi untuk implementasi bioengineering pertimbangan sosial ekonomi masyarakat, dimana nilai hasil produksi vegetasi juga perlu dipertimbangkan selain nilai ekologi dan mitigasi bencana. Beberapa vegetasi mempunyai nilai ekonomi yang baik sekaligus ekologis, akan tetapi pada tempo tertentu seiring dengan hilangnya nilai ekonomi (ditebang/dipanen) berakibat hilangnya fungsi/nilai ekologis secara keberlanjutan memberi potensi peluang terjadinya bahaya dan bencana alam seperti longsor.

\section{c. Pertimbangan Morfoekologis Tanaman (Mekanis dan Hidrologis)}

Pertimbangan morfologis tanaman juga perlu mendapat perhatian yaitu tanaman yang berkayu (pohon), mempunyai kanopi daun yang proporsional, berakar mencengkeram kuat yang 
bisa berfungsi sebagai angkur, membentuk ikatan yang kuat juga secara hidrologis mempunyai fungsi penyerap air hujan (intersepsi), mengendalikan kelembaban tanah yaitu fungsi penguapan, dan mengendalikan aliran permukaan dengan skema keseimbangan neraca air tanah mikro.

Perpaduan pertimbangan sosial ekonomi yang juga dikonsultasikan kepada masyarakat serta juga dengan pertimbangan morfoekologis tanaman, maka direkomendasikan tanaman sebagai berikut:

- Tanaman Pohon sebagai tanaman strata tinggi/atas dipilih tanaman Durian dan Pete. Tanaman ini secara pertimbangan sosial ekonomi dan morfoekologis sangat memenuhi syarat untuk diimplementasikan.

- Tanaman Kopi sebagai tanaman strata menengah. Secara sosial ekonomi bisa diterima oleh masyarakat, akan tetapi fungsi ekologisnya masih mempunyai peranan yang baik pada lahan berlereng dan karakter lahan seperti di Jatiradio, Cililin

- Tanaman Nanas sebagai tanaman strata bawah. Secara sosial ekonomi juga mempunyai manfaat yang baik bagi masyarakat petani penggarap lahan, pola pemanenannya hanya dipanen buah yang terdapat di atas pucuk rumpun daun, ada kecenderungan akan makin rimbun membentuk kanopi menutup permukaan tanah pada strata paling bawah yang mampu mengendalikan energi pukulan butiran air hujan.

- Tanaman Suren juga menjadi perhatian oleh petani karena bisa dipanen kayunya, akan tetapi jenis tanaman ini direkomendasikan diintroduksikan dengan intensitas yang rendah dan pada batas tanah antar bidang tanah.

\subsection{Desain yang Direkomendasikan}

Dengan pertimbangan sebagaimana tersebut di atas yaitu aspek ekonomi dan pertimbangan morfoekologis tanaman yang terkait dengan sifat mekanis dan hidrologis, maka direkomendasikan struktur implementasi tanaman vegetasi dalam kaitannya penerapan bioengineering pada kawasan rawan longsor di Desa Jatiradio, Kecamatan Cililin, Kabupaten Bandung Barat adalah sebagai berikut: jalur vegetasi tanaman Petai (Parkia speciosa) atau Durian (Durio zibenthinus) sebagai tanaman strata atas, berikutnya jalur tanaman Kopi (Coffea arabica) berada pada strata menengah dan di samping jalur tanaman strata atas dan menengah terdapat jalur tanaman Nanas (Ananas commocus) yang berada pada strata paling bawah. Perpaduan ini secara keseluruhan, canopy tanaman akan bisa menutupi permukaan tanah secara lebih sempurna sehingga curah hujan yang jatuh tidak langsung masuk ke permukaan tanah. Gambaran desain implementasi Bioenginering sebagaimana disajikan pada Gambar 5.

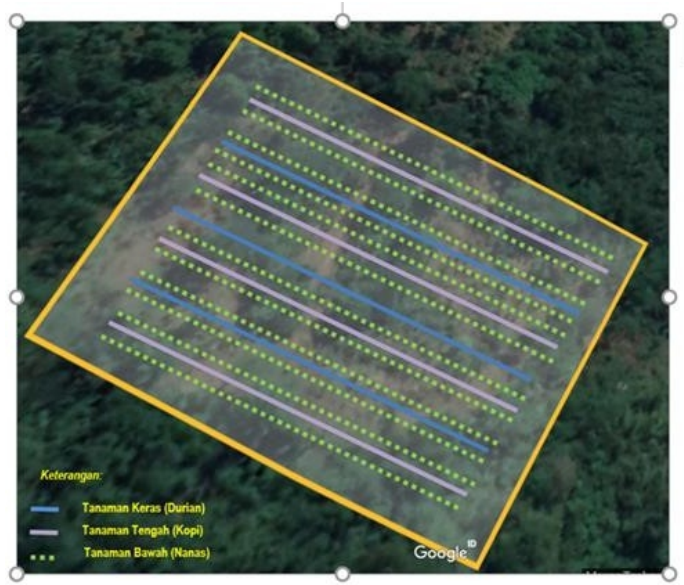

Gambar 5. Desain Implementasi Bioengineering dengan Variasi Starata Tanaman dan Jenis

\subsection{Pelaksanaan Implementasi}

\section{a. Pengadaan Bibit Tanaman}

Sesuai dengan perencanaan desain, bibit tanaman yang terpilih (Gambar 6) telah mempertimbangkan aspek sosial ekonomi dan ekologi. Tanaman yang terpilih juga terstruktur dari strata atas, menengah, dan bawah. Untuk strata atas yaitu tanaman Durian (Durio zibenthinus) dan Petai (Parkia speciosa). Tanaman tengah adalah tanaman Kopi (Coffea arabica) dan tanaman bawah adalah tanaman Nanas (Ananas commocus). Struktur tanaman ini dimaksudkan mengkondisikan lahan agar tertutup oleh kanopi tanaman seiring dengan tingkat umur dan perkembangan pertumbuhan tanaman. Sehingga berangsur lahan akan meningkatkan indeks tutupan lahannnya dan dampak lanjutannya sistem regim inflow dan outflow akan lebih stabil. Lahan juga akan lebih stabil dalam konteks kesetimbangan massa tanah dan neraca airnya. Gambaran jenis tanaman atau vegetasi diimplementasikan di lokasi Desa Jatiradio, Kecamatan Cililin, Kabupaten Bandung Barat. 


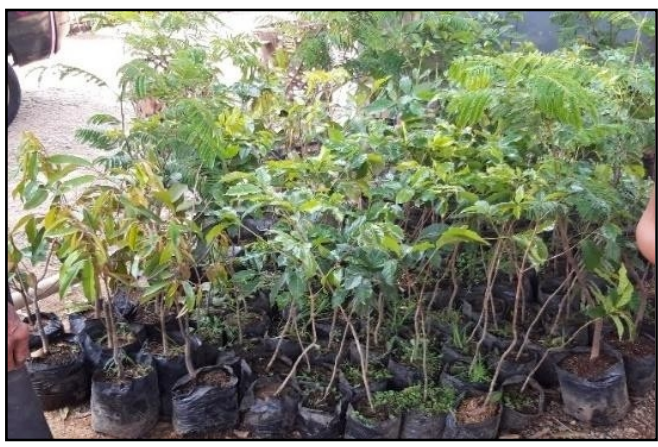

Gambar 6. Pengadaan Bibit Tanaman dari

Pusat Pembibitan di Parompong ke Cililin, Kab Bandung Barat

\section{b. Mobilisasi Bibit Tanaman ke Lokasi Implementasi}

Mengingat lokasi implementasi berada pada lereng bukit, maka mobilisasi bibit tanaman dilakukan secara bertahap. Tahap pertama dari lokasi pembibitan di Parompong, Kabupaten Bandung, dimobilisasi ke lokasi implementasi di Kecamatan Cililin. Lokasi droping bibit tanaman di Cililin yaitu di Pesantren Nurul Huda, Kecamatan Cililin. Dari lokasi pesantren ini tahap selanjunya adalah mobilisasi menuju lahan implementasi kurang lebih $300 \mathrm{~m}$ ke arah bukit (Gambar 7). Mobilisasi dari Parompong ke lokasi Cililin dengan menggunakan kendaraan pick up, sedangkan dari Pesantren ke lokasi lahan implementasi dengan mobilisasi konvensional (dipikul).

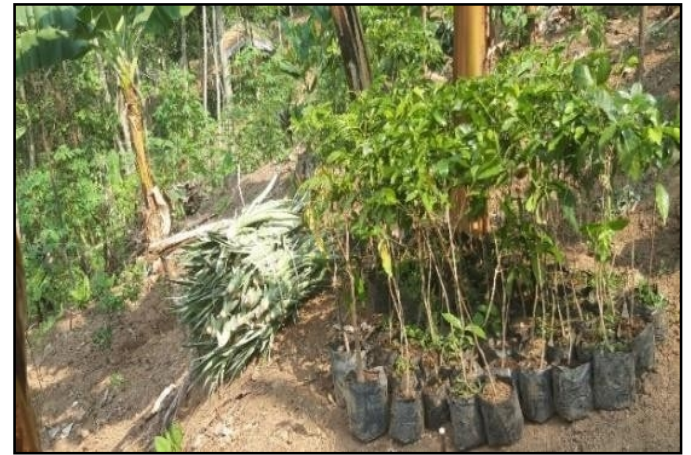

Gambar 7. Mobilisasi Bibit Tanaman ke Lokasi Lahan Implementasi Bioengineering

\section{c. Persiapan Lubang Tanam}

Pembuatan lubang tanaman (Gambar 8) dibuat sesuai dengan kondisi bibit tanaman dan jenis tanaman yang akan diimplementasikan. Untuk lubang tanaman strata tinggi, lubang tanaman dibuat dengan dimensi $50 \mathrm{~cm} \times 50 \mathrm{~cm} \times$
$60 \mathrm{~cm}$. Lubang dengan dimensi ini untuk jenis tanaman Durian (Durio zibenthinus) dan tanaman Petai (Parkia speciosa). Sementara untuk jenis tanaman Kopi (Coffea arabica) dimensi lubang tanaman $40 \times 40 \times 50 \mathrm{~cm}$. Untuk tanaman Nanas (Ananas commocus) lubang tanam $30 \times 30 \times 30$ $\mathrm{cm}$.

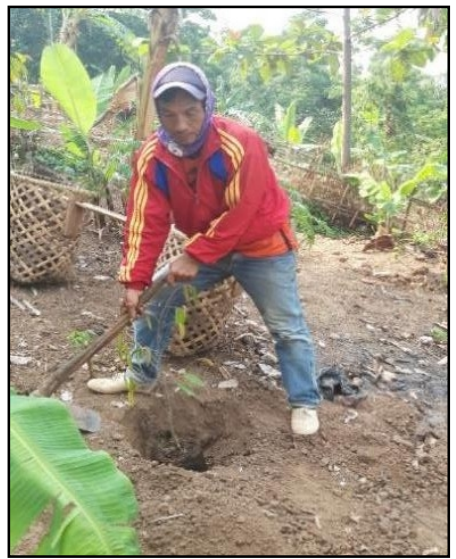

Gambar 8. Persiapan Lubang Tanam untuk Komoditas Durian (Durio zibenthinus)

\section{d. Penanaman}

Penanaman dilakukan sesuai dengan rencana jumlah tanaman yang diimplementasikan berdasarkan sistem jalur (Gambar 5). Perencanaan jalur tanaman sesuai dengan desain yang telah diusulkan sedikit ada modifikasi berdasarkan jumlah tanaman yang diadakan. Untuk Durian (Durio zibenthinus) sebanyak 2 (dua) jalur. Petai (Parkia speciosa) sebanyak 2 (dua) jalur, Kopi sebanyak 4 jalur, dan Nanas sebanyak 8 jalur. Jumlah tanaman Durian (Durio zibenthinus) sebanyak 40 batang, tanaman Petai (Parkia speciosa) sebanyak 50 batang, tanaman Kopi (Coffea arabica) sebanyak 150 batang, dan Nanas (Ananas commocus) sebanyak 1000 batang.

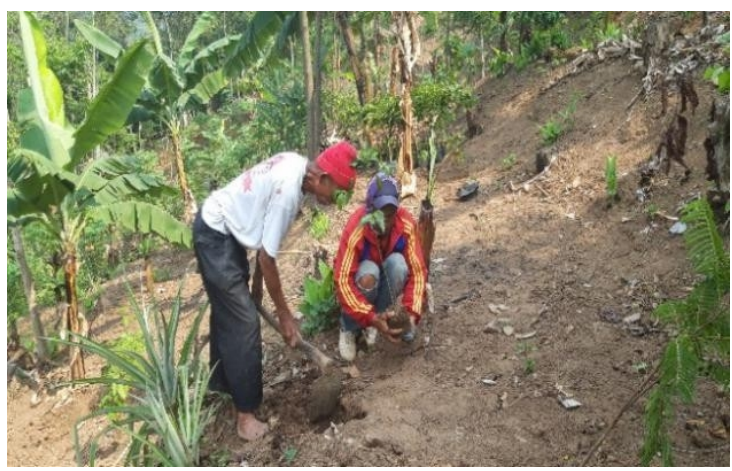

Gambar 9. Pelaksanaan Penanaman Vegetasi Bioengineering 


\subsection{Keseimbangan Neraca Air Pasca Implementasi}

Analisis neraca air sangat dipengaruhi berbagai faktor. Hal yang terkait dengan implementasi bioengineering ini adalah terkait vegetasi itu sendiri serta kondisi perilaku tanah dalam mengelola kandungan air. Terkait dengan vegetasi, implementasi vegetasi yang memperbaiki kondisi tutupan permukaan tanah tentunya akan mempengaruhi perilaku dan dinamika evapotranspirasi. Penguapan oleh permukaan kanopi tanaman dalam jumlah yang masif tentunya akan mempengaruhi keseimbangan neraca air kawasan. Selaian evaporasi terkait dengan hal ini adalah faktor limpasan. Dengan adanya perbaikan tutupan lahan dan kondisi perakaran vegetasi di tanah, maka limpasan yang terjadi juga akan terkendali dengan baik, sehingga limpasan permukaan yang terjadi akan lebih sedikit dibandingkan dengan kalau permukaan tanah tertutup oleh vegetasi yang lebih terbuka.

\section{KESIMPULAN}

Pendekatan implementasi bioengineering
dalam mitigasi bencana longsor perlu mempertimbangkan aspek biofisik lahan, ekologi, dan sosial ekonomi. Perpaduan ketiga faktor tersebut memungkinkan lahan yang telah dikelola secara intensif dapat dikendalikan faktor dinamis dan pemicu terjadinya bahaya longsor.

Implementasi bioengineering sebaiknya mempertimbangkan bukan semata ekologi saja tapi juga pertimbangan ekonomi dengan menerapkan tanaman pohon yang diambil buah atau bijinya serta pertimbangan tanaman strata menengah dan bawah yang juga diambil hanya buah dan bijinya.

Pemilihan jenis tanaman pohon sebagai strata atas yaitu Petai (Parkia speciosa) dan Durian (Durio zibenthinus), strata menengah yaitu Kopi (Coffea arabica) dan strata bawah yaitu Nanas (Ananas commocus) diterima sangat baik oleh petani pengelola lahan rawan longsor. Perpaduan ini dianggap sebagai pilihan yang masuk akal, baik memenuhi syarat pertimbangan sosial ekonomi maupun ekologi.

Perpaduan implementasi tanaman/vegetasi budidaya akan meningkatkan kekuatan lahan/tanah dalam mengkondisikan kestabilan kelembaban tanah. Implikasi dari keadaan ini hidrologi kawasan dapat terjaga sehingga bahaya longsor dapat dikendalikan.

\section{DAFTAR PUSTAKA}

Asdak, C. 2003. Faktor Hutan, Geomorfologi, dan Anomali Iklim pada Bencana Longsor di Hulu DAS Cimanuk. Prosiding Semiloka Mitigasi Bencana Longsor Di Kabupaten Garut. Pemerintah Kabupaten Garut.

Bradshaw, A. D. 1987. The reclamation of derelict land and the ecology of ecosystem. In W. R. Jordan, M. E. Gilpin, and J. D. Aber (eds.), Restoratio ecology: A Synthetic Approach to Ecological Research. Cambridge, UK: Cambridge University Press.

Gonzalez, A., dan S.B. Mickovski. 2017. Hydrological Effect of Vegetation Against Rainfall-Induced Landslides. Journal of Hydrology. Vol 549, June 2017, Pages 374387.

Gray, D. H. and A. T. Leiser. 1982. Biotechnical Slope Protection and Erosion Control. Van Nostrand Reinhold Company. New York

Hidayat, R., J.S. Samuel, dan D.M. Mohammad. 2016. Kondisi Geologi dan Pola Hujan Sebagai Pemicu Longsor di Jawa Tengah Bagian Selatan pada Juni 2016. Jurnal Teknik Hidraulik, Vol.7 No.2, Desember 2016: 147-146.

Huang, L. J. dan X.S. Lin. 2002. Study on landslide related to rainfall. Journal of Xiangtan Normal University (in Chinese, Natural Science Edition), 24(4): 5562.

Indracahya, M.B., Suwarno, dan Sutomo. 2015. Kajian Penggunaan Lahan Terhadap Kerawanan Longsorlahan Di SUB-DAS Logawa Kabupaten Banyumas, Jurnal Prosiding Seminar Nasional Pendidikan Geografi FKIP UMP. 13 Juni 2015, ISBN 978-602-74194-0-7.

Kawamoto, K., Oda, M., dan Suzuki, K. 2000. Hydro-geological study of landslides caused by heavy rainfall on August 1998 in Fukushima, Japan. Journal of Natural Disaster Science, 22(1): 13-23.

Kurnia, U., Sudirman, dan H. Kusnadi. 2005. Rehabilitasi dan Reklamasi Lahan Terdegradasi. hlm 147-182 dalam: Teknologi Pengelolaan Lahan Kering Menuju Pertanian Produktif dan Ramah Lingkungan. Pusat Penelitian dan Pengembangan Tanah dan Agroklimat. Badan Penelitian dan Pengembangan Pertanian. Departemen Pertanian.

Morgan, RPC. 1986. Soil Erotion and Conservation. Longman Sci \& Tech. Essex. England. 
Rawls, W.J., D. Gime'nez \& R. Grossman. 1998. Use of soil texture, bulk density and slope of the water retention curve to predict saturated hydraulic conductivity. Transactions of the American Society of Agricultural Engineers, 41, 983-988.

Rupaka, G. 2015. Analisis Kesesuaian Penggunaan Lahan pada Daerah Rawan Bencana Tanah Longsor

Singh, A. N., A.S. Raghubanshi and J. S. Singh. 2002. Plantations as a tool for mine spoil restoration. Current Science, 82(12): 14361441.

Torbert, J. L., J.A. Burger and W.L. Daniels. 1993. Pine growth variation associated with overburden rock type on a reclaimed surface mine in Virginia. Journal of Environmental Quality, 19: 88-92.

Varnes, D.J. 1958. Slope Movement Types and Processes. Special Report, Washington, D.C. 